\title{
Eco Mobility World Festival 2013 Suwon: an analysis of changes in citizens' awareness and satisfaction
}

\author{
Suk Hee Kim ${ }^{\text {a }}$, Kyu Jin Lee ${ }^{\text {b, }}$, Keechoo Choi ${ }^{c}$ \\ ${ }^{a}$ Urban and Environmental Research Division, Suwon Research Institute \\ 111 Maeyeong-ro 345 beon-gil Yeongtong-gu, Suwon-si Gyeonggi-do, South Korea \\ ${ }^{b}$ TOD based Sustainable Urban Transportation Research Center, Ajou University \\ 206 World cup-ro Yeongtong-gu, Suwon-si Gyeonggi-do \\ ${ }^{c}$ Department of Engineering, Ajou University \\ 206 World cup-ro Yeongtong-gu, Suwon-si Gyeonggi-do
}

\begin{abstract}
In the existing policy framework for the expansion of transportation facilities, in order for sustainable green growth, there has been a paradigm shift towards reducing impacts to the urban environment and realizing a low-carbon ecological polis. In particular, there has been a necessity for a mobility management policy framework that can change peoples' psychological and environmental perceptions to induce a willingness to change individual behaviors towards the reduction of private vehicle use. In line with these policy needs, Suwon City in South Korea implemented a Korean mobility management policy framework through the EcoMobility World Festival 2013. This study analyzed citizens' awareness and satisfaction of residential environments. Through the analysis, this study provides a practical approach for the effective implementation of ecological polis projects. The results of the analysis of the satisfaction with residential environments found that the festival contributed to an overall improvement in citizens' satisfaction with the pedestrian environment and air and noise quality. The improvement was found to be attributed to advertising in the media, holding public consultations and participating in the EcoMobolity World Fesitval 2013 Suwon. Particularly, the analysis showed a change in peoples' perceptions towards an interest in pollution in the environment and the importance of people over private vehicles. While there were negative perceptions and concerns towards a car-free city prior to the festival, upon experiencing ecomobility through the festival, overall satisfaction increased among citizens. While there were various obstacles throughout the preparation stages, after the festival, citizens' awareness of the coexistence between the natural environment and people was widespread and led to a shift in citizens' awareness. The shift in awareness levels is expected to be a driving force in establishing a mobility management policy framework, and the results of this study will contribute as valuable policy implications in proposing a policy framework for future ecological polis projects.
\end{abstract}

Keywords: EcoMobility; Ecological Polis; EcoMobility World Festival 2013 Suwon; Car-free City; Green City; Air Quality; Pedestrian Environment; Urban Regeneration

\section{INTRODUCTION}

The issues pertaining to the concept of green cities and ecological polices stretch further than the existing notions of sustainability, environmentally-friendly development and climate change, to include the fundamental change of our fossil fuel and carbon-oriented city structures to low-carbon-oriented city structures. In order to realize these cities, the importance of transportation policies is continuing to increase. In other words, there is a shift in paradigm from the existing policies pertaining to the expansion of transportation facilities to policies that reduce impacts on the urban environment, realize low-carbon ecological polices and enhance sustainable and green growth. There is a growing concern for the necessity for mobility management policies that shift peoples' psychological and environmental awareness and perceptions, while instilling voluntary changes to travel behavior in order to reduce the usage of private vehicles. Loukopoulos et al. (2005) claimed that an individual's level of awareness has a greater influence on the usage of a private vehicle, in comparison to socio-economic factors that restrict private vehicle usage, such as the ownership of a private vehicle and household income. Furthermore, according to Johansson et al. (2006), concerns for the environment, perception of safety, convenience and comfort have a strong influence on mode choice and travel patterns. In response to these policy needs, Suwon city in South Korea implemented a Korean mobility management model through the EcoMobility World Festival 2013 Suwon $^{1}$. This study analyzes citizens' perceptions and satisfaction of the

\footnotetext{
* Corresponding author. Tel.: +82-031-219-3252; fax: +82-031-219-3253

E-mail address: transjin@ajou.ac.kr

${ }^{1}$ An ecological polis project by the ICLEI and UN-Habitat that changed the Haenggung-dong neighbourhood in Suwon, South Korea to a car-free neighbourhood during the month of September 2013.
} 
neighborhood's environment in order to provide a practical approach for the effective implementation of ecological polis projects.

\section{Introduction to the EcoMobility World Festival 2013 Suwon}

\subsection{Concept and policies of ecomobility}

The Global Alliance for EcoMobility defines ecomobility as the usage of environmentally-friendly transport modes such as walking, cycling, public transport, wheeling (using any man powered vehicle with wheels), other forms of non-motorized transport and light electric-powered vehicles (using renewable energy sources) in order to enhance citizens' quality of life, widen the options for mode choice, promote social cohesion and include vulnerable persons. Based on these principles, the EcoMobility World Festival 2013 Suwon was proposed for the Haenggung-dong neighborhood in Suwon, South Korea, with an area of $0.34 \mathrm{~km}^{2}$. The neighborhood has a population of 4,343 and houses 2,220 households. In addition, Haenggung-dong served as Suwon's old city center and is a symbolic and cultural neighborhood holding the Hwaseong Fortress which was designated as a World Heritage site by the United Nations Educational, Scientific and Cultural Organization (UNESCO) in 1997. Furthermore, neighborhood is protected as a cultural heritage site, which limits development; as a result, the neighborhood can be characterized as lagging in comparison to other neighborhoods. Nevertheless the neighborhood's infrastructure and facilities were improved through the EcoMobility World Festival 2013 Suwon and the neighborhood was revitalized, resulting in an urban regeneration effect. The following policy directions were proposed for the EcoMobility World Festival 2013 Suwon: 1) the construction of ecomobility infrastructure, 2) support for citizens' lifestyles and 3) operation of cultural festivals.

\subsection{Construction of ecomobility infrastructure}

In order to shift private vehicle users to walk and use environmentally-friendly transport modes, before the implementation of the project, a variety of ecomobility infrastructure was constructed to transform the neighborhood into a pedestrian-friendly environment. The construction included the implementation of planting strips along the selected ecomobility streets and old alleyways and the expansion of pedestrian sidewalks (and the subsequent narrowing of the roadways) in order to improve the pedestrian environment. In addition, the unused spaces in the neighborhood were reconstructed as parks where pedestrians could rest and enjoy leisure activities. Various measures were taken to improve the old city center's residential environment, such as the construction of building signs and green buildings, removal of walls, facade improvements of old apartments and the undergrounding of overhead power lines.

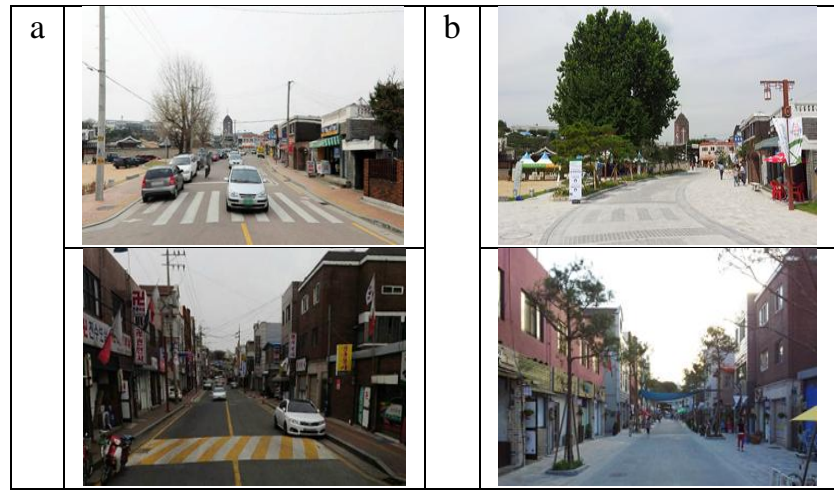

Fig. 1. Construction of the ecomobility neighborhood (a) before improvements; (b) after improvements.

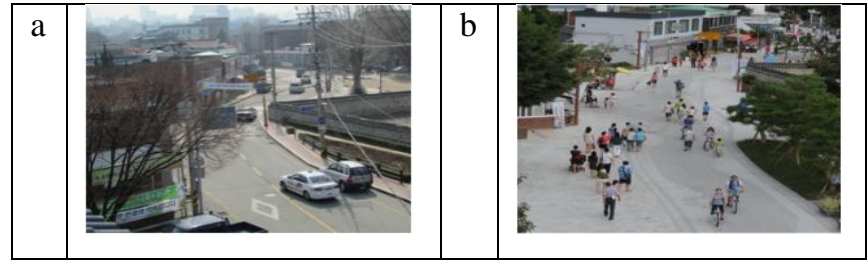




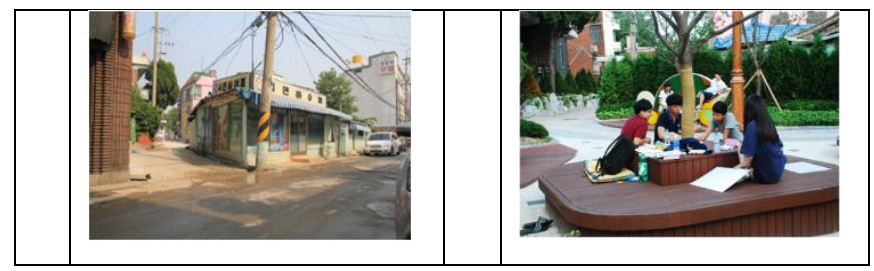

Fig. 2. Construction of the ecomobility neighborhood (a) before improvements; (b) after improvements.

\subsection{Support for citizens' convenience}

As the daily life of the citizens of the Haenggung-dong neighborhood is connected with the policy framework, support for the neighborhood's citizens was a priority in implementing the festival. In order to integrate citizens' opinions, door-to-door surveying was performed on numerous occasions. In order for citizens to carry out a car-free lifestyle during the festival, alternate ecomobility transport modes were provided and temporary parking lots outside of the neighborhood (5 parking lots with a total of 1,620 lots) were constructed. A free shuttle bus service was provided to transport citizens between the neighborhood and the newly constructed temporary parking lots in order to reduce any inconvenience for citizens. In addition, in order to vitalize commercial activities in the neighborhood, an EcoMobility Festival coupon was established and a Haenggung-dong cultural market was proposed to support long-term, sustainable cultural commercial activities.

\subsection{Cultural festival program}

For the duration of the EcoMobility World Festival 2013 Suwon, various hands-on activities, festival events and exhibitions were carried out in order for visitors to the neighborhood to better understand and experience ecomobility. Different activities, events and exhibitions were carried out for citizens, children and citizens. For citizens, activities included bike taxi riding, ecomobility community dancing, guided tours through the ecomobility neighborhood and an exhibition of old photos collected from citizens. For children, activities included an ecomobility urban camp, special session for future generations, in addition to hands-on activities where children could ride different types of bicycles, experience urban farming and attend learning sessions on the environment. For citizens, activities included ecomobility parades, a contest for ecomobility policy ideas, street festival with the participation of commercial businesses, operation of food and snack stands, among other various cultural festival programs. In addition, the exhibitions of various non-motorized transportation modes and tram system (which is to be implemented by Suwon City) allowed for citizens to be better acquainted with different types of transport modes.

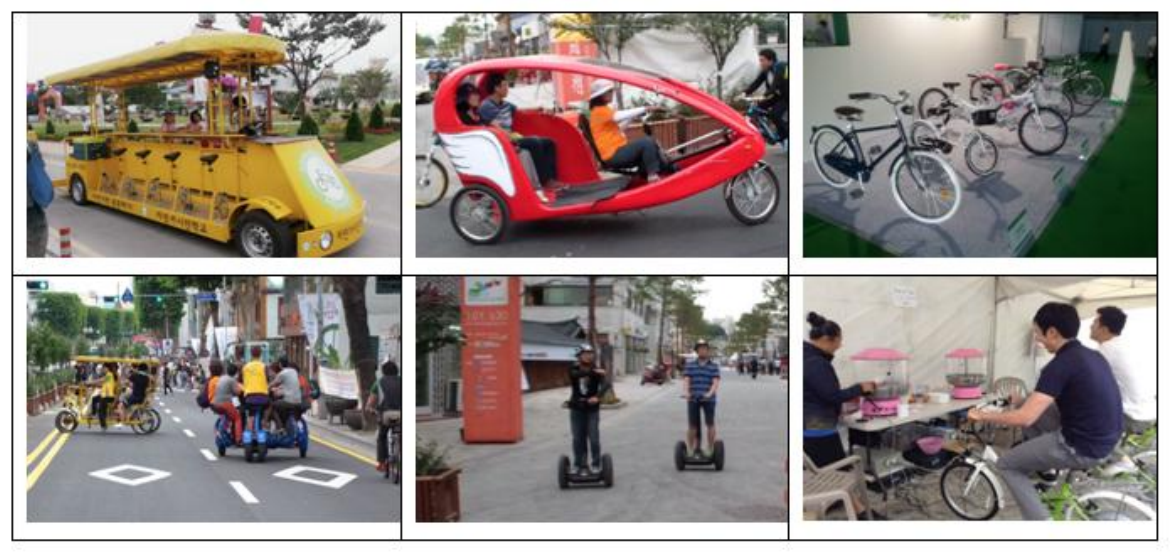

Fig. 3. Hands-on activities and exhibitions

2. nalysis of changes in citizens' satisfaction and awareness

\subsection{Overview of interview surveys}

In order to assess the successful implementation of the EcoMobility World Festival 2013 Suwon, surveys were carried out before and after the festival. To analyze the enhancement of promotion and awareness and the neighborhood's environment, the citizens and workers of the Haenggung-dong neighborhood were surveyed face-to-face. To analyze the change in awareness and travel behavior after the festival, surveying was performed two months after the end of the festival. An overview of the survey contents are shown in the following table. 
EcoMobility World Festival 2013 Suwon: an analysis of changes in citizens' awareness and satisfaction

Table 1. Overview of survey, performed before and after the festival.

\begin{tabular}{|c|c|c|c|c|c|c|c|c|c|c|c|}
\hline & \multicolumn{5}{|c|}{ Before festival } & \multicolumn{6}{|c|}{ After festival } \\
\hline Sex & \multicolumn{3}{|l|}{ Male } & \multicolumn{2}{|l|}{ Female } & \multicolumn{3}{|l|}{ Male } & \multicolumn{3}{|l|}{ Female } \\
\hline $\begin{array}{l}\text { Number of } \\
\text { Respondents } \\
(\%)\end{array}$ & \multicolumn{3}{|l|}{$\begin{array}{l}2,228 \\
(49 \%)\end{array}$} & \multicolumn{2}{|l|}{$\begin{array}{l}2,323 \\
(51 \%)\end{array}$} & \multicolumn{3}{|c|}{$\begin{array}{l}363 \\
(44.8 \%)\end{array}$} & \multicolumn{3}{|l|}{$\begin{array}{l}404 \\
(49.9 \%)\end{array}$} \\
\hline Age Group & $\begin{array}{l}\text { Below } \\
20\end{array}$ & $20-29$ & $30-49$ & $50-64$ & $65+$ & $10-19$ & $20-29$ & $30-39$ & $40-49$ & $50-59$ & $60+$ \\
\hline $\begin{array}{l}\text { Number of } \\
\text { Respondents } \\
(\%)\end{array}$ & $\begin{array}{l}369 \\
(8.2 \%)\end{array}$ & $\begin{array}{l}570 \\
(12.7 \%)\end{array}$ & $\begin{array}{l}1,450 \\
(32.4 \%)\end{array}$ & $\begin{array}{l}1,205 \\
(26.8 \%)\end{array}$ & $\begin{array}{l}895 \\
(19.9 \%)\end{array}$ & $\begin{array}{l}45 \\
(5.6 \%)\end{array}$ & $\begin{array}{l}85 \\
(10.5 \%)\end{array}$ & $\begin{array}{l}98 \\
(12.1 \%)\end{array}$ & $\begin{array}{l}117 \\
(14.4 \%)\end{array}$ & $\begin{array}{l}181 \\
(22.3 \%)\end{array}$ & $\begin{array}{l}269 \\
(33.2 \%)\end{array}$ \\
\hline Survey Contents & \multicolumn{5}{|c|}{$\begin{array}{l}\text { Respondents' general characteristics, ecomobility } \\
\text { awareness and residential environment satisfaction, } \\
\text { household travel survey, ecomobility participation, } \\
\text { demand for transport modes (other than private } \\
\text { vehicle) }\end{array}$} & \multicolumn{6}{|c|}{$\begin{array}{l}\text { Respondents' general characteristics, neighborhood } \\
\text { satisfaction, level of inconvenience (private vehicle), } \\
\text { environment, changes in peoples' perception, participation in } \\
\text { and satisfaction with the festival, future direction of } \\
\text { neighborhood development, behavioral changes related to } \\
\text { transport }\end{array}$} \\
\hline Survey Period & \multicolumn{5}{|c|}{$\begin{array}{l}\text { One year prior to the festival } \\
2012.8 .20 \sim 2012,9.18\end{array}$} & \multicolumn{6}{|c|}{$\begin{array}{l}\text { Two months after the festival } \\
\text { 2013.11.1. 2013.12.15 }\end{array}$} \\
\hline Survey Contents & \multicolumn{5}{|c|}{ 1:1 Interview } & \multicolumn{6}{|c|}{ 1:1 Interview } \\
\hline
\end{tabular}

\subsection{Analysis of the impact of the EcoMobility World Festival 2013 Suwon}

An impact analysis of the festival was performed in order to assess the effectiveness of the festival. Through surveys, the impact analysis was carried out to measure the change in the level of citizens' awareness on environmental issues, such as climate change, the importance of people over vehicles and the degree to which citizens' quality of life were enhanced. The analysis results show changes in satisfaction with residential environment, awareness of ecomobility, perception of the environment and whether private vehicle users switched their mode choice to alternate ecomobility transport modes.

\subsection{Change in satisfaction with residential environment}

After comparing the overall satisfaction of the neighborhood, it was found to have greatly improved after the festival. In the case of the pedestrian environment, while negative responses were predominant before the festival, with $24.1 \%$ negative responses and $19.8 \%$ positive responses, after the festival, negative responses decreased to $16.1 \%$ and positive responses increased to $49.3 \%$. As a result, the satisfaction with the pedestrian environment improved greatly after the festival. The increase in positive responses is attributed to the improvements made to the pedestrian environment in the preparation stages of the festival through the repavement of roads and undergrounding of overhead electric poles. In comparison to the existing neighborhood conditions, various improvements were made to better the walking environment. In addition, positive responses increased in terms of the satisfaction with the air and noise quality. Overall, the satisfaction with the residential environment improved in all areas.

Table 2. Cross-tabulation of neighborhood satisfaction (pedestrian environment, air and noise quality), before and after the festival.

\begin{tabular}{|c|c|c|c|c|c|c|c|c|c|c|c|c|}
\hline & \multicolumn{2}{|c|}{$\begin{array}{l}\text { Very } \\
\text { dissatisfie } \\
\text { d }\end{array}$} & \multicolumn{2}{|c|}{$\begin{array}{l}\text { Dissatisfie } \\
\text { d }\end{array}$} & \multicolumn{2}{|c|}{ Average } & \multicolumn{2}{|c|}{ Satisfied } & \multicolumn{2}{|c|}{$\begin{array}{l}\text { Very } \\
\text { satisfied }\end{array}$} & \multicolumn{2}{|l|}{ Total } \\
\hline & $\begin{array}{l}\text { Bef } \\
\text { ore }\end{array}$ & $\begin{array}{l}\text { Afte } \\
\mathrm{r}\end{array}$ & $\begin{array}{l}\text { Bef } \\
\text { ore }\end{array}$ & $\begin{array}{l}\text { Afte } \\
\mathrm{r}\end{array}$ & $\begin{array}{l}\text { Bef } \\
\text { ore }\end{array}$ & $\begin{array}{l}\text { Afte } \\
\mathrm{r}\end{array}$ & $\begin{array}{l}\text { Bef } \\
\text { ore }\end{array}$ & $\begin{array}{l}\text { Afte } \\
\mathrm{r}\end{array}$ & $\begin{array}{l}\text { Bef } \\
\text { ore }\end{array}$ & $\begin{array}{l}\text { Afte } \\
\mathrm{r}\end{array}$ & $\begin{array}{l}\text { Befor } \\
\text { e }\end{array}$ & After \\
\hline $\begin{array}{l}\text { Pedest } \\
\text { rian } \\
\text { Numb } \\
\text { er of } \\
\text { respon } \\
\text { ses } \\
(\%)\end{array}$ & $\begin{array}{l}104 \\
(3 . \\
2 \% \\
)\end{array}$ & $\begin{array}{l}57 \\
(5.2 \\
\%)\end{array}$ & $\begin{array}{l}672 \\
(20 . \\
9 \%)\end{array}$ & $\begin{array}{l}120 \\
(10 . \\
9 \%)\end{array}$ & $\begin{array}{l}1,79 \\
9 \\
(56 . \\
0 \%)\end{array}$ & $\begin{array}{l}379 \\
(34 . \\
5 \%)\end{array}$ & $\begin{array}{l}555 \\
(17 . \\
3 \%)\end{array}$ & $\begin{array}{l}348 \\
(31 . \\
7 \%)\end{array}$ & $\begin{array}{l}80 \\
(2.5 \\
\%)\end{array}$ & $\begin{array}{l}193 \\
(17 . \\
6 \%)\end{array}$ & $\begin{array}{l}3,210 \\
(100.0 \\
\%)\end{array}$ & $\begin{array}{l}1,097 \\
(100 . \\
0 \%)\end{array}$ \\
\hline $\begin{array}{l}\text { Air } \\
\text { Numb }\end{array}$ & $\begin{array}{l}49 \\
(1 .\end{array}$ & $\begin{array}{l}32 \\
(2.9\end{array}$ & $\begin{array}{l}416 \\
(13 .\end{array}$ & $\begin{array}{l}89 \\
(8.2 \\
\end{array}$ & $\begin{array}{l}1,99 \\
6\end{array}$ & $\begin{array}{l}515 \\
(47 .\end{array}$ & $\begin{array}{l}647 \\
(20 .\end{array}$ & $\begin{array}{l}318 \\
(29 .\end{array}$ & $\begin{array}{l}86 \\
(2.7\end{array}$ & $\begin{array}{l}132 \\
(12 .\end{array}$ & $\begin{array}{l}3,194 \\
(100.0\end{array}$ & $\begin{array}{l}1,086 \\
(100 .\end{array}$ \\
\hline
\end{tabular}




\begin{tabular}{|c|c|c|c|c|c|c|c|c|c|c|c|c|}
\hline $\begin{array}{l}\text { er of } \\
\text { respon } \\
\text { ses } \\
(\%)\end{array}$ & $\begin{array}{l}5 \% \\
)\end{array}$ & $\%)$ & $0 \%)$ & $\%)$ & $\begin{array}{l}62 . \\
5 \%)\end{array}$ & $4 \%)$ & $3 \%)$ & $3 \%)$ & $\%)$ & $2 \%)$ & $\%)$ & $0 \%)$ \\
\hline Noise & 72 & 69 & 440 & 128 & 1,92 & 464 & 687 & 291 & 84 & 137 & 3,203 & 1,089 \\
\hline $\begin{array}{l}\text { Numb } \\
\text { er of } \\
\text { respon } \\
\text { ses } \\
(\%)\end{array}$ & $\begin{array}{l}(2 . \\
2 \%\end{array}$ & $\begin{array}{l}(6.3 \\
\%)\end{array}$ & $\begin{array}{l}(13 . \\
7 \%)\end{array}$ & $\begin{array}{l}(11 . \\
8 \%)\end{array}$ & $\begin{array}{l}0 \\
(59 . \\
9 \%)\end{array}$ & $\begin{array}{l}(42 . \\
6 \%)\end{array}$ & $\begin{array}{l}(21 . \\
4 \%)\end{array}$ & $\begin{array}{l}(26 . \\
7 \%)\end{array}$ & $\begin{array}{l}(2.6 \\
\%)\end{array}$ & $\begin{array}{l}(12 . \\
6 \%)\end{array}$ & $\begin{array}{l}(100.0 \\
\%\end{array}$ & $\begin{array}{l}(100 . \\
0 \%)\end{array}$ \\
\hline
\end{tabular}

\subsection{Change in level of awareness and interest in ecomobility}

From before and after the festival, the level of awareness of the term ecomobility had greatly increased. Respondents who had not known the term decreased from $74.3 \%$ to $2.7 \%$, while those who had known the term greatly increased from $7.3 \%$ to $56.0 \%$. This sharp increase in the level of awareness is attributed to the advertisements through various forms of media, public consultations and the participation of citizens in the EcoMobility World Festival 2013 Suwon during the month of September. Given the sharp increase in the level of awareness of ecomobility among the citizens, future ecomobility policies proposed by the city are thought to engage citizen participation. After the EcoMobility World Festival 2013 Suwon, Suwon City Hall proposed a "car-free road" project as initiated by a group of citizens in Suwon. The project has seen a high degree of participation among citizens. The change in citizens' level of interest of pollution in the environment has also increased through the festival. The share of respondents who indicated their level of interest of pollution in the environment has "increased" to "greatly increased" made up $70.4 \%$ of all responses. This increase in the level of interest is attributed to the festival.

Table 3. Change in level of interest of pollution in the environment.

\begin{tabular}{|l|l|l|l|l|l|l|l|l|}
\hline & $\begin{array}{l}\text { Greatly } \\
\text { increased }\end{array}$ & $\rightrightarrows$ & $\rightrightarrows$ & Increased & $\rightrightarrows$ & $\rightrightarrows$ & $\begin{array}{l}\text { No } \\
\text { change } \\
\text { in } \\
\text { interest }\end{array}$ & Total \\
\hline $\begin{array}{l}\text { Number } \\
\text { of } \\
\text { responses }\end{array}$ & 193 & 60 & 122 & 394 & 131 & 100 & 93 & 1,093 \\
\hline$(\%)$ & $(17.7 \%)$ & $(5.5 \%)$ & $(11.2 \%)$ & $(36.0 \%)$ & $(12.0 \%)$ & $(9.1 \%)$ & $(8.5 \%)$ & $100.0 \%$ \\
\hline
\end{tabular}

Citizens showed an increase in terms of the perception that pedestrians are more important than vehicles, where the proportion of respondents who indicated an "increase" was 35.4\% and "greatly increased" was $15.8 \%$.

Table 4. Change in perception of pedestrians' importance over vehicles.

\begin{tabular}{|l|l|l|l|l|l|l|l|l|}
\hline & $\begin{array}{l}\text { Greatly } \\
\text { increased }\end{array}$ & $\rightrightarrows$ & $\rightrightarrows$ & Increased & $\rightrightarrows$ & $\rightrightarrows$ & $\begin{array}{l}\text { No } \\
\text { change in } \\
\text { perception }\end{array}$ & Total \\
\hline $\begin{array}{l}\text { Number } \\
\text { of } \\
\text { responses }\end{array}$ & 173 & 53 & 63 & 387 & 154 & 136 & 126 & 1,092 \\
\hline$(\%)$ & $(15.8 \%)$ & $(4.9 \%)$ & $(5.8 \%)$ & $(35.4 \%)$ & $(14.1 \%)$ & $(12.5 \%)$ & $(11.5 \%)$ & $(100.0 \%)$ \\
\hline
\end{tabular}

Through the EcoMobility World Festival 2013 Suwon, street spaces appropriate for ecomobility were used as community spaces and changes were seen in terms of the consideration for people in the neighborhood and urban environment. The changes in perception towards environmental issues and the importance of people positively increased through the ecomobility initiatives. In order to sustain the change in perception in individual behavior, a sustainable mobility management policy framework is seen as necessary. 


\subsection{Attitudes and willingness to participate}

In analyzing the attitudes towards ecomobility, in comparison to the attitudes before the festival, satisfaction levels after the festival positively increased. Before the festival, $18.3 \%$ of responses were positive and $26.9 \%$ of responses were negative. However, after the festival, positive responses increased to $33.2 \%$ and negative responses decreased to $24.2 \%$. In particular, the "very negative" responses reduced from $23.7 \%$ to $11.7 \%$, which shows a reduction in the number of citizens who held extremely negative attitudes towards ecomobility. Given the factors that influenced the citizens' negative attitudes and concerns towards a car-free neighborhood before the festival, through participating in the festival and experiencing the benefits of a car-free neighborhood, the overall satisfaction and attitudes positively increased.Comparing the willingness to participate before the festival and the actual level of participation, it was found that, overall, actual levels of participation were greater. This level of participation can be attributed to the various governance organizations that were established in the preparation stages of the festival; the diligent activities carried out by the organizations instilled a level of consensus among citizens to actively participate in the festival, thereby positively influencing the actual level of participation of citizens in the festival.
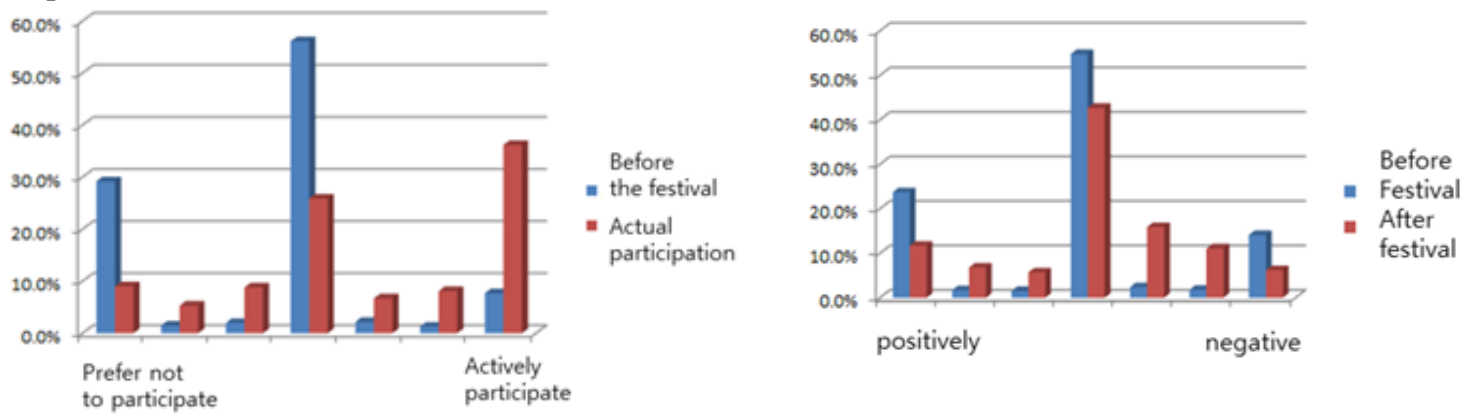

Fig. 4. Participation in and satisfaction with the festival (a) willingness to participate and actual level of participation; (b) attitudes and level of satisfaction.

\subsection{Change in private vehicle users' behaviors}

After improving the neighborhood to be pedestrian-oriented, respondents' level of change in vehicle speeds were as follows: "no change" with 211 respondents $(52.8 \%)$ was greatest, followed by "decreased vehicle speed" with $45.0 \%$ and "increased vehicle speed" with $2.3 \%$. The following measures were taken for drivers to decrease vehicle speeds: road widths were narrowed, roads were repaved and roads were reconstructed as curved roads, and were seen the main factors in reducing vehicle speeds.

Table 5. Change in vehicle speeds upon pedestrian-oriented improvements to the neighborhood.

\begin{tabular}{|l|l|l|l|l|}
\hline & $\begin{array}{l}\text { Decreased } \\
\text { vehicle } \\
\text { speed }\end{array}$ & $\begin{array}{l}\text { Increased } \\
\text { vehicle } \\
\text { speed }\end{array}$ & $\begin{array}{l}\text { No change } \\
\text { to vehicle } \\
\text { speed }\end{array}$ & Total \\
\hline $\begin{array}{l}\text { Number of } \\
\text { responses }\end{array}$ & 180 & 9 & 211 & 400 \\
\hline$(\%)$ & $(45.0 \%)$ & $(2.3 \%)$ & $(52.8 \%)$ & $(100.0 \%)$ \\
\hline
\end{tabular}

\subsection{Shift in mode choice}

The neighborhoods which adopted the car-free neighborhood concepts were Sinpung-dong and Jangan-dong. The citizens in the two neighborhoods were surveyed to analyze changes to mode choice. Citizens' choice of transport modes before, during and after the festival were analyzed. It was found that a citizens shifted their mode choice to an extent.

- Mode choice of the neighborhood area

In comparison to citizens' mode choices before the festival, during the festival private vehicle use greatly decreased and walking and cycling increased. Before the festival, modal share was as follows: 583 respondents indicated "walking" (53.7\%), 344 respondents indicated "private vehicle" (31.7\%) and 78 respondents indicated "cycling" (6.2\%). During the festival, 753 respondents indicated "walking" (70.0\%), 157 respondents indicated "cycling" (14.6\%) and 71 respondents indicated "other" (6.6\%) as their mode choice. After the festival, 583 respondents indicated "walking" (54.2\%), 316 respondents indicated "private vehicle" (29.4\%) and 89 respondents indicated "cycling" (8.3\%) as their mode choice. 
During the festival, the shift from private vehicles to walking or cycling can be attributed to the convenience of walking, cycling or other modes of transport to access the neighborhood as private vehicles were to be parked in the temporary parking lots outside of the neighborhood. While after the festival private vehicle use increased, in comparison to before the festival, private vehicle use decreased and walking and cycling increased. The small increase in walking and cycling may be attributed to seasonal factors, as the survey was performed during winter.

Table 6. Changes in mode choice of the neighborhood area.

\begin{tabular}{|c|c|c|c|c|c|c|}
\hline \multirow{2}{*}{$\begin{array}{l}\text { Transport } \\
\text { mode }\end{array}$} & \multicolumn{2}{|c|}{ Before festival } & \multicolumn{2}{|c|}{ During festival } & \multicolumn{2}{|c|}{ After festival } \\
\hline & $\begin{array}{l}\text { Number } \\
\text { of } \\
\text { responses }\end{array}$ & $(\%)$ & $\begin{array}{l}\text { Number } \\
\text { of } \\
\text { responses }\end{array}$ & $(\%)$ & $\begin{array}{l}\text { Number } \\
\text { of } \\
\text { responses }\end{array}$ & $(\%)$ \\
\hline $\begin{array}{l}\text { Private } \\
\text { vehicle }\end{array}$ & 344 & $(31.70 \%)$ & 68 & $(6.30 \%)$ & 316 & $(29.40 \%)$ \\
\hline Bicycle & 67 & $(6.20 \%)$ & 157 & $(14.60 \%)$ & 89 & $(8.30 \%)$ \\
\hline Motorcycle & 28 & $(2.60 \%)$ & 20 & $(1.90 \%)$ & 23 & $(2.10 \%)$ \\
\hline $\begin{array}{l}\text { Electric } \\
\text { wheel chair }\end{array}$ & 3 & $(0.30 \%)$ & 6 & $(0.60 \%)$ & 3 & $(0.30 \%)$ \\
\hline Walking & 583 & $(53.70 \%)$ & 753 & $(70.00 \%)$ & 583 & $(54.20 \%)$ \\
\hline Other & 60 & $(5.50 \%)$ & 71 & $(6.60 \%)$ & 62 & $(5.80 \%)$ \\
\hline Total & 1,085 & $(100 \%)$ & 1,075 & $(100 \%)$ & 1,076 & $(100 \%)$ \\
\hline
\end{tabular}

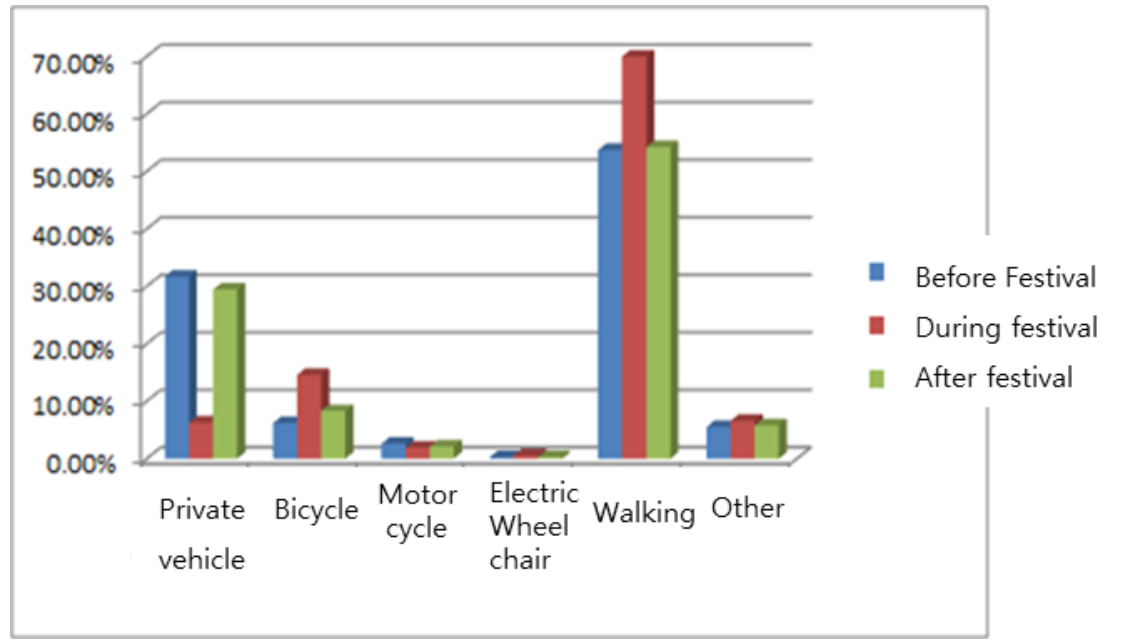

Fig. 5. Changes in mode choice of the neighborhood area.

- Mode choice for commuting

In order to measure the change in mode choice (from private vehicle to an alternative transport mode) during the festival, survey respondents were surveyed on their main mode choice for their daily travel needs, such as commuting to work and school and other daily tasks. Before the festival, mode choice for commuting was "private vehicle" for 297 respondents (82.3\%), "public transit" for 24 respondents (6.6\%) and "walking" for 19 respondents $(5.3 \%)$. During the festival, mode choice for commuting was "private vehicle" for 185 respondents (52.1\%), "public transit" for 94 respondents (26.5\%) and "walking" for 32 respondents (9.0\%); private vehicle users decreased by $30 \%$ and public transit users greatly increased. While the increase in public transit use is attributed to the inconvenience for private vehicle users to park outside of the neighborhood in the temporary parking lots, due to the long average commuting distances, the proportion of the shift in mode choice for commuting is less in comparison to that of the shift in mode choice for the neighborhood area. After the festival, mode choice for commuting was "private vehicle" for 278 respondents (78.8\%), "public transit" for 31 respondents $(8.8 \%)$ and "walking" for 18 respondents $(5.1 \%)$. While in comparison to the mode choice for commuting during the festival, private vehicle use increased, in comparison to that of before the festival, private 
vehicle use slightly decreased and public transit use increased. The slight decrease in walking after the festival may be attributed to seasonal factors, as the survey was performed in the winter.

Table 7. Change in mode choice for commuting.

\begin{tabular}{|l|l|l|l|l|l|l|}
\hline \multirow{2}{*}{$\begin{array}{l}\text { Transport } \\
\text { mode }\end{array}$} & \multicolumn{2}{|l|}{ Before festival } & \multicolumn{2}{l|}{ During festival } & \multicolumn{2}{l|}{ After festival } \\
\cline { 2 - 7 } & $\begin{array}{l}\text { Number } \\
\text { of } \\
\text { responses }\end{array}$ & $(\%)$ & $\begin{array}{l}\text { Number } \\
\text { of } \\
\text { responses }\end{array}$ & $(\%)$ & $\begin{array}{l}\text { Number } \\
\text { of } \\
\text { responses }\end{array}$ & $(\%)$ \\
\hline $\begin{array}{l}\text { Private } \\
\text { vehicle }\end{array}$ & 297 & $(82.3 \%)$ & 185 & $(52.1 \%)$ & 278 & $(78.8 \%)$ \\
\hline Public transit & 24 & $(6.6 \%)$ & 94 & $(26.5 \%)$ & 31 & $(8.8 \%)$ \\
\hline Bicycle & 7 & $(1.9 \%)$ & 18 & $(5.1 \%)$ & 13 & $(3.7 \%)$ \\
\hline Motorcycle & 6 & $(1.7 \%)$ & 7 & $(2.0 \%)$ & 6 & $(1.7 \%)$ \\
\hline Walking & 19 & $(5.3 \%)$ & 32 & $(9.0 \%)$ & 18 & $(5.1 \%)$ \\
\hline Other & 8 & $(2.2 \%)$ & 19 & $(5.4 \%)$ & 7 & $(2.0 \%)$ \\
\hline Total & 361 & $(100.0 \%)$ & 355 & $(100.0 \%)$ & 353 & $(100.0 \%)$ \\
\hline
\end{tabular}

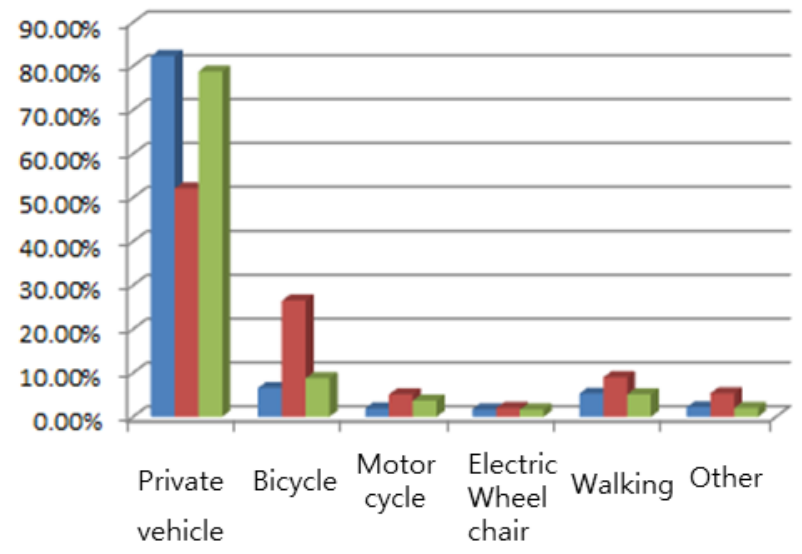

Before Festival

- During festival

after festival

Fig. 6. Change in mode choice for commuting.

\section{CONCLUSION}

This study performed an impact analysis comparing the effectiveness of the EcoMobility World Festival 2013 Suwon.In comparing citizens' satisfaction with the residential environment, satisfaction with the pedestrian environment and air and noise quality were positively improved after the festival. In terms of awareness, the level of awareness of ecomobility greatly increased through advertisements in the media, public consultations and participation in the EcoMobility World Festival 2013 Suwon. The analysis found that citizens became more interested in pollution in the environment and more perceptive of the importance of people over vehicles. It is expected that these changes in awareness levels will be a driving force in establishing a mobility management policy framework.The results of analyzing citizens' shift in mode choice show that in comparison to before the festival, where private vehicle use was $82.3 \%$, during the festival, private vehicle use decreased by $30.1 \%$. In addition, there was a significant shift in mode choice towards environmentally-friendly transport modes such as public transit and cycling. In particular, after the festival, modal share of private vehicle use decreased by $3.5 \%$ from before the festival. It was found that the festival could shift peoples' travel behavior in a sustainable manner. Most importantly, the shift in peoples' perceptions towards the environment and importance of people in the urban system through ecomobility presents implications for the need of a sustainable mobility management policy framework in order to induce individual behavioral changes. 


\section{ACKNOWLEDGEMENTS}

This work was supported by SRI-POLICY-2013-4 of Suwon Research Institute and the National Research Foundation of Korea grant funded by the Korea Government(MSIP) (NRF-2010-0028693).

\section{REFERENCES}

[1] Jan Scheurer(2001), Residential Areas for Households without Cars: The Scope for Neighbourhood Mobility Management in Scandinavian Cities, Trafikdage på Aalborg Universitet, pp165-176.

[2] Kim J. K., Oh D. S. (2007), Analysis on the Sustainability and Design Strategies of German Ecological Housing Estates according to Development Stages, Journal of Urban Design Institute of Korea, 8(4), Urban Design Institute of Korea, pp105-286.

[3] Lee W. R., Im Y. B. (2009), A Study on Sustainable Element of Ecological Housing Complex, KPA Spring Annual Conference, Korea Planners Association, pp279-286.

[4] Michael Ornetzedera, Edgar G. Hertwichb, Klaus Hubacekc, Katarina Korytarovad, Willi Haase (2008), The environmental effect of car-free housing: A case in Vienna, Ecological Economics, 65(3), The International Society for Ecological Economics, pp516-530.

[5] Johansson, M, V,. Heldt, T. and Johansson, P. (2006), The Effects of Attitudes and Personality Traits on Mode Choice, Transportation Research Part A 40, Amsterdam: Elsevier. pp507-525.

[6] Loukopoulos, P., Jakobsson, C., Garling, T., Schneider, C.M. and Fujii, S. (2005), Public Attitudes towards Policy Measures for Reducing Private Car Use: Evidence from a Study in Sweden, Environmental Science \& Policy 8. New York: Elsevier. pp57-66.

[7] Suwon City (2012), "Establishment of the traffic flow management plan for the EcoMobility World Festival 2013 Suwon"

[8] Suwon City (2012), "Study of citizens' awareness and household travel survey for the implementation of the EcoMobility World Festival 2013 Suwon"

[9] Suwon City (2012), "Establishment of the basic plan and feasibility study for the ecomobility pilot project"

[10] Suwon Research Institute (2013), "Study on the policy implications of the impact analysis of the EcoMobility World Festival 2013 